\title{
Dinamika Dan Perkembangan Peraturan Pada Masa Pandemi Covid 19 Dalam Perspektif Tanggung Jawab Negara
}

\author{
Sudjana \\ Fakultas Hukum, Universitas Padjadjaran \\ Email:sdjana@yahoo.com
}

Article info

Received: Sep 8, $2021 \quad$ Revised: Oct 14, $2021 \quad$ Accepted: Oct 22, $2021 \quad$ Published: Dec 9, 2021

DOI: https://doi.org/10.31599/krtha.v15i2.809

Keywords : Regulations, Covid 19, Liability

Abstract : Handling the Covid 19 pandemic through statutory policies is a liability that needs to be implemented in the concept of a welfare state but needs to be supported by active community participation. The approach method used is normative juridical and juridical empirical, data collection techniques are derived from secondary data, and data analysis is normative qualitative. The results of the study show that the liability of the State through statutory policies in stages in bandling the Covid 19 pandemic has been implemented according to the concept of a welfare state because the state has undertaken an obligation to fulfill its character in providing special protection, so that it becomes the source of all laws and regulations in social affairs. However, efforts to fulfill the State's liability are associated with the legal system, according to Friedman, which is still constrained by the low legal culture of society in adhering to it.

Kata kunci : Peraturan, Covid 19, Tanggung jawab

Abstrak : Penanganan Pandemi Covid 19 melalui kebijakan perundang-undangan merupakan tanggung jawab yang perlu diimplementasikan dalam konsep negara kesejahteraan tetapi perlu didukung partisipasi aktif masyarakat. Metode pendekatan yang digunakan yuridis normatif dan dan yuridis empiris, Teknik pengumpulan data bersumber dari data sekunder, dan analisis data bersifat normatif kualitatif. Hasil kajian menunjukan tanggung jawab Negara melalui kebijakan perundangundangan secara bertahap dalam Penanganan Pandemi covid 19 telah diimplementasikan sesuai konsep negara kesejahteraan karena negara telah melakukan kewajiban untuk memenuhi karakter dalam memberikan perlindungan secara khusus, sehingga menjadi sumber dari semua peraturan perundangundangan dalam urusan sosial tetapi upaya pemenuhan tanggung Jawab Negara tersebut dikaitkan dengan sistem hukum menurut Friedman masih terkendala rendahnya budaya hukum masyarakat dalam mentaatinya. 


\section{PENDAHULUAN}

Kesehatan merupakan salah satu indikator kesejahteraan umum, ${ }^{1}$ sehingga setiap hal yang menyebabkan terjadinya gangguan kesehatan pada masyarakat Indonesia menimbulkan kerugian ekonomi yang besar bagi negara, dan setiap upaya peningkatan derajat kesehatan masyarakat juga berarti investasi bagi pembangunan Negara. ${ }^{2}$ Hal ini mengingat kesehatan tidak hanya terhindar dari penyakit phisik tetapi adalah keadaan sehat, baik secara fisik, mental, spritual maupun sosial yang memungkinkan setiap orang untuk hidup produktif secara sosial dan ekonomis. ${ }^{3}$

Pada Desember 2019 dilaporkan pertama kali di Wuhan, Provinsi Hubei, timbul kasus pneumonia atau gejala awal penderita yaitu demam hingga letih dan lesu. Sumber penularan kasus ini masih belum pasti, tetapi kasus pertama dikaitkan dengan pasar ikan di Wuhan. ${ }^{4}$ Tanggal 18 Desember hingga 29 Desember 2019, terdapat 5 pasien yang dirawat dengan Acute Respiratory Distress Syndrome (ARDS). ${ }^{5}$ Sejak 31 Desember 2019 hingga 3 Januari 2020 kasus ini meningkat pesat, ditandai dengan dilaporkannya sebanyak 44 kasus. Lebih lanjut tidak sampai satu bulan, penyakit ini telah menyebar di berbagai provinsi lain di China, Thailand, Jepang, dan Korea Selatan. ${ }^{6}$

Menurut WHO (2020), sejak Januari 2020, Corona Virus Disease-19 (COVID-19) telah menginfeksi lebih dari 2.245.872 jiwa di seluruh dunia dan Lebih dari 152.000 orang terkonfirmasi meninggal dunia karena virus ini. Oleh karena itu, Negara-negara berusaha untuk melakukan berbagai kebijakan untuk menangani COVID-19 dengan pendekatannya masing-masing. Di China, misalnya, pemerintah merespons wabah Covid19 dengan menyediakan fasilitas kesehatan khusus pasien virus korona, mengubah gedung olahraga, aula, sekolah, dan juga hotel menjadi rumah sakit sementara, melalukan rapid-test ataupun polymerase chain reaction (PCR) terhadap warga, hingga mengimplementasikan

1 https://www.kompasiana.com/icai/54ff1 feda333112e4550f95f/indikator-kesejahteraan (diakses 3 Januari 2021).

${ }^{2}$ Bagian Menimbang huruf C UU No. 36 Tahun 2009 tentang Kesehatan.

${ }^{3}$ Ibid, Pasal 1 angka (1).

${ }^{4}$ Rothan HA, Byrareddy SN. "The epidemiology and pathogenesis of coronavirus disease (COVID19) outbreak". J Autoimmun. 2020; published online March 3. DOI: 10.1016/j.jaut.2020.102433 (diakses 4 Januari 2021).

${ }^{5}$ Ren L-L, Wang Y-M, Wu Z-Q, Xiang Z-C, Guo L, Xu T, et al. "Identification of a novel coronavirus causing severe pneumonia in human: a descriptive study". Chin Med J. 2020; published online February 11. DOI: 10.1097/CM9.0000000000000722 (diakses 4 Januari 2021).

${ }^{6}$ Huang C, Wang Y, Li X, Ren L, Zhao J, Hu Y, et al. "Clinical features of patients infected with 2019 novel coronavirus in Wuhan, China”. Lancet. 2020:395 (10223):497-506. Lihat juga Adityo Susilo et al, Coronavirus Disease 2019: "Tinjauan Literatur Terkini Coronavirus Disease 2019: Review of Current Literatures", Jurnal Penyakit Dalam Indonesia Vol. 7, No. 1 Maret (2020): 46. 
metode mengisolasi kota (lockdown). ${ }^{7}$ Di Daegu, Korea Selatan, pendeteksian dini melalui rapid test dilakukan secara massal dengan tujuan melokalisasi individu yang terpapar Covid19 sebagai upaya preventif untuk meminimalkan penyebaran virus corona, meliburkan sekolah dan kampus, dan melaksanakan lockdown. ${ }^{8}$

WHO telah menetapkan Virus Covid-19 sebagai pandemi yang mengancam kehidupan umat manusia, sehingga setiap Negara berusaha untuk melakukan berbagai upaya penanganan baik preventif maupun kuratif. Penanganan Covid 19 yang lamban berpotensi menjadi episentrum dunia setelah Wuhan, ${ }^{9}$ karena itu pemerintah Indonesia mengeluarkan berbagai kebijakan sebagai solusi terhadap penyebaran covid 19 yang banyak menelan korban. Seiring waktu, angka kasus positif Covid-19 terus mengalami lonjakan sehingga Jumlah kasus positif corona telah mencapai 59.394 orang yaitu dari sejumlah 29.740 pasien masih berada dalam perawatan, 26.667 pasien dinyatakan sembuh, dan 2.987 pasien lainnya meninggal dunia. Penyakit Covid-19 telah menyebar luas di 34 provinsi dan 440 kabupaten/kota di Indonesia. Dari 34 provinsi tersebut, 5 provinsi dengan kasus positif Covid-19 tertinggi adalah Jawa Timur (21, 3 persen), DKI Jakarta (20, 1 persen), Sulawesi Selatan (9 persen), Jawa Tengah (6, 9 persen), dan Jawa Barat (5, 7 persen) hingga 2 Juli 2020..$^{10}$ Di tingkat dunia, Indonesia menempati urutan ke-29 kasus sebaran Covid-19 dari 216 negara yang sudah terpapar virus tersebut, dan menurut WHO, jumlah kasus corona tercatat 10.533.779 dengan 512.842 kasus kematian. Amerika Serikat (AS) masih menempati urutan teratas negara dengan kasus Covid-19 terbanyak di dunia, yakni 2.616.949 kasus positif. Disusul kemudian Brasil (1.402.041 kasus), Rusia (661.165 kasus), India (604.641 kasus), Inggris (313.487 kasus), Peru (285.213 kasus), Chile (282.043 kasus), Spanyol (249.659 kasus), Italia (240.760 kasus), dan Iran (230.211 kasus). Di kawasan Asia Tenggara, Indonesia menempati urutan pertama kasus positif korona

\footnotetext{
${ }^{7}$ Aida, N.R. "Rekap Perkembangan Virus Corona Wuhan dari Waktu ke Waktu". (Kompas Online, 28 Januari 2020, hlm 1-2). Retrieved from https://www. kompas.com/tren/read/2020/01/ 28/054600665/rekap-perkembanganvirus-corona-wuhan-dari-waktu-ke-waktu (diakses 7 Januari 2021).

${ }^{8}$ Park, S.N. (2020). "Cults and Conservatives Spread Coronavirus in South Korea Seoul seemed to have the virus under control. But religion and politics have derailed plans". (Foreign Policy Online, 27 Februari 2020). Retrieved from https://foreignpolicy.com/2020/02/27/coronavirus-south-korea-cultsconservativeschina/ (diakses 9 Januari 2021).

9 Sari, H.P, "Indonesia disebut Berpotensi Jadi Episentrum Baru Covid-19", Ini Respons Jubir Pemerintah. (Kompas Online, 11 April 2020). Retrieved from https://nasional. Kompas $\mathrm{com} / \mathrm{read} / 2020 / 04 / 11 / 20351811 /$ indonesia-disebut berpotensi -jadi-episentrum-baru-covid-19-inirespons-jubir (diakses 10 Januari 2021). Lihat juga Leo Agustino, “Analisis Kebijakan Penanganan Wabah COVID-19: Pengalaman Indonesia”, Jurnal Borneo Administrator, Vol. 16 No. 2, 253-270, Agustus (2020): 254.

10 https://kompaspedia.kompas.id/baca/paparan-topik/merunut-kebijakan-penanganan-wabahcovid-19-di-indonesia (diakses 12 Januari 2021).
} 
sejak 17 Juni 2020. Posisi berikutnya diduduki oleh Singapura (44.122 kasus), Filipina (38.511 kasus), Malaysia (8.640 kasus), dan Vietnam (355 kasus). ${ }^{11}$

Menurut Kompas com, Data Covid-19 di Indonesia, update 31 Desember 2020, 20:06 WIB menyebutkan: terkonfirmasi 743,198+8,074 kasus; dirawat 109,963, 14.796\% dari terkonfirmasi; meninggal 22,138, 2.979\% dari terkonfirmasi; dan sembuh 611,097, $82.225 \%$ dari terkonfirmasi. ${ }^{12}$ Berdasarkan data terakhir hingga Senin (25/1/2021), kasus infeksi virus corona di Indonesia tercatat 999.256, sehingga Indonesia menempati posisi 19 dalam peringkat negara dengan kasus terbanyak berdasarkan data Worldometers. ${ }^{13}$

Untuk menekan kuantitas angka penyebaran covid 19, pemerintah melakukan berbagai kebijakan. Di bidang kesehatan, Kementerian Kesehatan menyiapkan 132 rumah sakit rujukan dengan kapasitas 40.829 tempat tidur untuk fokus menangani pasien Covid19. Selain itu, tercatat 40.320 dokter spesialis yang disiagakan untuk menangani pasien Covid-19 yang tersebar di 2.877 rumah sakit, baik RS milik pemerintah maupun swasta, dan 2 juta obat Avigan, menyusul pemesanan 5 ribu obat yang sama sebelumnya. Selain Avigan, pemerintah juga memesan 3 juta Klorokuin ${ }^{14}$ dan melakukan metode 3T yakni pemeriksaan dini (testing), pelacakan (tracing), dan perawatan (treatment).

Di bidang hukum, pemerintah melakukan kebijakan legislasi berkaitan dengan Pembatasan Sosial Berskala Besar (PSBB), pengadaan dan pelaksanaan vaksinasi dan protokol kesehatan yang dituangkan dalam bentuk pengesahan beberapa peraturan seperti Peraturan Pemerintah, Keputusan Menteri Kesehatan dan sebagainya. Kebijakan legislasi tersebut didasarkan pada peraturan perundang-undangan yang ada sebelum terjadinya pandemi covid 19 seperti UU No 4 Tahun 1984 tentang Wabah Penyakit Menular jo Peraturan Pemerintah No.40 Tahun 1991 tentang Penanggulangan Wabah Penyakit Menular; UU No. 24 Tahun 2007 tentang Penanggulangan Bencana; UU No. 36 Tahun 2009 tentang Kesehatan; dan UU No.6 Tahun 2018 tentang Kekarantinaan Kesehatan.

Dinamika dan Perkembangan peraturan perundang-undangan yang dilakukan secara bertahap sejak tahun 2019 melalui berbagai jenis yaitu Peraturan Pemerintah; Peraturan Presiden; Keputusan Presiden; Instruksi Presiden; Peraturan Menteri; Keputusan Menteri, Keputusan Direktur Jenderal dilatarbelakangi oleh pentingnya penanganan covid 19 tersebut secara efektif, efisien dan terpadu sehingga setiap

11 Ibid.

${ }^{12}$ https://www.kompas.com/covid-19 (diakses 13 Januari 2021).

${ }^{13}$ Luthfia Ayu Azanella, "Kasus Covid-19 Hampir 1 Juta, Penanganan Pandemi di Indonesia Belum "On the Right Track"", https://www.kompas.com/tren/read/2021/01/26/125900965/kasus-covid-19hampir-1-juta-penanganan-pandemi-di-indonesia-belum-on-the (diakses 13 Januari 2021).

14 https://kompaspedia.kompas.id/baca/paparan-topik/merunut-kebijakan-penanganan-wabahcovid-19-di-indonesia (diakses 12 Januari 2021). 
peraturan baru yang disahkan saat terjadinya pandemi covid 19 harus ditujukan pada upaya untuk mewujudkan pemenuhan kesehatan rakyat sebagai bentuk tanggung jawab Negara berdasarkan UUD 1945. Ketentuan Pasal 28H ayat (1) UUD 1945 Amandemen IV mengatakan bahwa: "Setiap orang berhak hidup sejahtera lahir dan batin, bertempat tinggal, dan mendapat lingkungan hidup yang baik dan sehat serta berhak memperoleh pelayanan kesehatan."Ketentuan tersebut mengisyaratkan bahwa kesehatan adalah hak dasar yang pelaksanaannya tidak hanya urusan individu sebagai karunia Tuhan Yang Maha Kuasa, tetapi merupakan tanggung jawab Negara dalam menjamin terwujudnya salah satu tujuan Negara yaitu "memajukan kesejahteraan umum." Hal ini tidak berarti bahwa rakyat tidak berupaya untuk mewujudkan kesejahteraan bagi dirinya sendiri, tetapi rakyat mempunyai hak dan kewajiban untuk mencapai kesejahteraannya, sedangkan Negara bertugas untuk menciptakan kondisi yang memungkinkan rakyat dapat menikmati hakhaknya sebagai warga Negara dalam mencapai tingkat kesejahteraannya sesuai konsep negara kesejahteraan yang dianut Indonesia. Namun, implementasi tanggung jawab Negara melalui kebijakan legislasi dalam penanganan pandemi covid 19 mengalami kendala karena ternyata penyebarannya masih cukup tinggi bahkan cenderung meningkat. Hal ini mengingat keberhasilan penanganan pandemi covid 19 harus dilakukan secara holistik artinya tidak hanya ditentukan melalui kebijakan perundang-undangan secara bertahap tetapi juga memerlukan adanya unsur-unsur lain yang merupakan suatu sistem yang terpadu. Berkaitan dengan sistem hukum, Friedman menjelaskan bahwa efektivitas atau keberhasilan penerapan sistem hukum ditentukan oleh unsur-unsurnya yaitu struktur hukum (legal structure), substansi hukum (legal substance), dan budaya hukum (legal culture) yang ketiganya memiliki hubungan fungsional.

Berdasarkan hal itu, rumusan masalah dalam kajian ini adalah (1) Bagaimana tanggung jawab Negara melalui kebijakan perundang-undangan secara bertahap dalam penanganan pandemi covid 19 dikaitkan dengan konsep Negara kesejahteraan? (2) Bagaimana kendala penanganan pandemi covid 19 dalam upaya pemenuhan tanggung jawab Negara dikaitkan dengan sistem hukum menurut Friedman?

\section{METODE PENELITIAN}

Metode pendekatan yang digunakan dalam kajian ini adalah pendekatan yuridis normatif, ${ }^{15}$ untuk mengkaji tanggung jawab Negara melalui kebijakan perundang-undangan secara

15 Peter Mahmud Marzuki, Penelitian Hukum, (Jakarta :Kencana Prenada Media Group, 2009), hlm. 
bertahap. Pendekatan tersebut meneliti bahan pustaka atau data sekunder sebagai bahan dasar untuk diteliti dengan mengadakan penelusuran terhadap peraturan-peraturan yang berkaitan dengan permasalahan yang diteliti, ${ }^{16}$ yaitu penanganan pandemi covid 19. Sedangkan pendekatan yuridis empiris untuk mengkaji kendala dalam upaya pemenuhan tanggung jawab Negara melalui kebijakan legislasi dalam mengimplementasikan konsep negara kesejahteraan, sehingga melihat hukum dalam kenyataannya (law in action). Dengan demikian, pendekatan yuridis empiris dipilih karena metode ini berupaya untuk melihat hukum dalam arti yang nyata atau dapat melihat, meneliti bekerjanya hukum dalam masyarakat. ${ }^{17}$ Teknik pengumpulan data bersumber dari data sekunder yang meliputi bahan hukum primer (perundang-undangan), bahan hukum sekunder (pendapat para akhli) dan bahan hukum tersier (kamus, internet dan lain sebagainya). Analisis data dilakukan secara normatif kualitatif yaitu untuk menghasilkan data deskriptif berdasarkan kajian kaidah dan asas perundang-undangan serta penafsiran hukum, sehingga perhitungan data tidak menggunakan rumus statistik.

\section{PEMBAHASAN}

\section{Tanggung jawab Negara melalui Kebijakan Perundang-undangan secara bertahap dalam Penanganan Pandemi Covid 19 dikaitkan dengan Konsep Negara Kesejahteraan}

Mustopadidjaja sebagaimana dikutip oleh Tahir ${ }^{18}$ menjelaskan, bahwa istilah kebijakan lazim digunakan dalam kaitannya atau kegiatan pemerintah, serta perilaku negara pada umumnya dan kebijakan tersebut dituangkan dalam berbagai bentuk peraturan yaitu ketentuan yang mengikat warga kelompok masyarakat, dipakai sebagai panduan, tatanan, dan kendalikan tingkah laku yang sesuai dan diterima: setiap warga masyarakat harus menaati aturan yang berlaku; atau ukuran, kaidah yang dipakai sebagai tolok ukur untuk menilai atau membandingkan sesuatu. ${ }^{19}$ Menurut James E Anderson kebijaksanaan Negara adalah kebijaksanaan yang dikembangkan oleh badan-badan dan pejabat-pejabat pemerintah. Implikasi dari pengertian kebijakan (pemerintah) tersebut adalah kebijakan negara itu selalu mempunyai tujuan tertentu atau merupakan tindakan-tindakan yang

\footnotetext{
16 Soerjono Soekanto \& Sri Mamudji, Penelitian Hukum Normatif (Suatu Tinjauan Singkat), (Jakarta : Rajawali Pers, 2011), hlm. 13-14.

17 Ana Silviana, "Kajian Tentang Kesadaran Hukum Masyarakat dalam Melaksanakan Pendaftaran Tanah”, Jurnal Pandecta Volume 7. Nomor 1. Januari (2012): 115.

18 Tahir, Arifin, Kebijakan Publike \& Transparansi Penyelenggaran Pemerintab Daerah, (Bandung: Penerbit Alfabeta, 2014), hlm. 21.

${ }^{19}$ Kamus Bahasa Indonesia tersedia dalam https://carapedia.com/pengertian definisi peraturan info2113.html (diakses 14 Januari 2021).
} 
berorientasi pada tujuan dan setidak-tidaknya dalam arti yang positif didasarkan atau selalu dilandasi pada peraturan-peraturan perundangan yang bersifat memaksa (otoritarif). ${ }^{20}$

Pengertian kebijakan menurut pendapat Said Zainal Abidin sebagaimana dikutip oleh dalam Dedy Mulyadii ${ }^{21}$, dapat dibedakan dalam tiga tingkatan:

a. Kebijakan Umum, yaitu kebijakan yang menjadi pedoman atau petunjuk pelaksanaan baik yang bersifat positif ataupun yang bersifat negatif yang meliputi keseluruhan wilayah atau instansi yang bersangkutan.

b. Kebijakan pelaksanaan, adalah kebijakan yang menjabarkan kebijakan umum. Untuk tingkat pusat, peraturan pemerintah tentang pelaksanaan suatu undangundang.

c. Kebijakan teknis, yaitu kebijakan operasional yang berada dibawah kebijakan pelaksanaan.

Penanganan pandemi covid 19 termasuk kebijakan pelaksanaan dan kebijakan teknis karena menjabarkan kebijakan umum yang menjadi pedoman sebagaimana tercantum dalam UU No 4 Tahun 1984 tentang Wabah Penyakit Menular; UU No. 24 Tahun 2007 tentang Penanggulangan Bencana; UU No. 36 Tahun 2009 tentang Kesehatan; dan UU No.6 Tahun 2018 tentang Kekarantinaan Kesehatan kedalam Peraturan Pemerintah, Peraturan atau keputusan Presiden, Peraturan atau keputusan Menteri, Direktur Jenderal, dan Gubernur serta walikota.

Kebijakan mempunyai beberapa implikasi, yaitu sebagai berikut: ${ }^{22}$

a. Kebijakan publik itu dalam bentuk perdananya berupa penetapan tindakantindakan dari Pemerintah.

b. Kebijakan publik itu tidak cukup hanya dinyatakan tetapi dilaksanakan dalam bentuk yang nyata.

c. Kebijakan publik itu, baik untuk melakukan sesuatu itu mempunyai dan dilandasi dengan maksud dan tujuan tertentu.

d. Kebijakan publik itu harus senantiasa ditujukan bagi kepentingan seluruh anggota masyarakat.

20 Selengkapnya lihat http:// id.shvoong.com/ writing-and-speaking/ presenting/2202699pengertian- kebijakan/ \# ixzz2Fs6 QdboO, (diakses 16 Januari 2021).

${ }^{21}$ Dedy Mulyadi, 2015, Studi Kebijakan Publik dan Pelayanan Publik, (Bandung :Penerbit Alfabeta, 2015), hlm. 38-39.

22 Edy Sutrisno, Mengenal Perencanaan, Implementsi \& Evaluasi Kebijakan/Program, (Surabaya: Penerbit, Untag Press, 2009), hlm. 16. 
Implikasi kebijakan tersebut, apabila dikaitkan dengan penanganan pandemi covid 19, berbentuk penetapan tentang Pembatasan Sosial Berskala Besar (PSBB), penyediaan dan pemberian vaksinasi dan protokol kesehatan yang telah dilakukan secara nyata dengan tujuan untuk menghilangkan atau meminimalkan penyebaran covid 19 dalam upaya memajukan kesejahteraan umum melalui pemenuhan hak atas kesehatan bagi setiap orang sebagai implementasi konsep Negara kesejahteraan (Welfare State) yang perinciannya tercantum dalam UUD 1945 terutama pasal-pasal yang berkaitan dengan sosial (termasuk kesehatan) dan ekonomi.

Kebijakan legislasi merupakan ranah politik hukum yang bersifat mendasar dalam menentukan arah, bentuk maupun isi dari hukum yang akan dibentuk dan dijadikan kriteria untuk menghukumkan sesuatu, ${ }^{23}$ karena itu politik hukum merupakan aktivitas memilih dan mekanisme yang digunakan dalam rangka mencapai tujuan sosial dan hukum tertentu dalam masyarakat ${ }^{24}$ yang diwujudkan dalam pembentukan perundang-undangan yaitu pembuatan peraturan perundang-undangan yang mencakup tahapan perencanaan, penyusunan, pembahasan, pengesahan atau penetapan, dan pengundangan. Peraturan perundang-undangan adalah peraturan tertulis yang memuat kaidah hukum yang mengikat secara umum dan dibentuk atau ditetapkan oleh lembaga negara atau pejabat yang berwenang melalui prosedur yang ditetapkan dalam peraturan perundang-undangan. ${ }^{25}$

Jenis peraturan perundang-undangan ${ }^{26}$ dibuat oleh badan tertentu sesuai dengan kewenangannya ${ }^{27}$, sedangkan hierarkhimemiliki makna kekuatan hukum atau daya mengikatnya, yaitu peraturan yang lebih rendah tidak mengikat jika bertentangan dengan peraturan yang lebih tinggi (lex superior derogate lege inferiori). Hans Kelsen, pelopor teori jenjang kaidah hukum (Stufentheorie) menyatakan bahwa kaidah hukum itu tersusun secara berjenjang dan berlapis dalam suatu hirarki (tata susunan) kaidah hukum. Norma hukum yang lebih rendah berlaku, bersumber, dan berdasar pada kaidah hukum yang lebih tinggi dan seterusnya sampai pada kaidah hukum yang paling tinggi yang tidak dapat ditelurusi

${ }^{23}$ Padmo Wahyono dalam Mahfud MD, Politik Hukum di Indonesia (Jakarta: Rajawali, 2010), hlm. 1. Lihat juga Mia Kusuma Fitriana, "Peranan Politik Hukum Dalam Pembentukan Peraturan PerundangUndangan Di Indonesia Sebagai Sarana Mewujudkan Tujuan Negara", Jurnal Legislasi Indonesia, (2018):7. https://e-jurnal.peraturan.go.id/ index. php/ jli/ issue/view/65 (diakses 17 Januari 2021).

${ }^{24}$ Satjipto Rahardjo dalam Mahfud MD, Membangun Politik Hukum, menegakean Konstitusi, Jakarta: Rajawali Press, 2011), hlm.15.

25 Pasal 1 ayat (2) UU No.15 Tahun 2019, loc.cit.

${ }^{26}$ Ibid, Pasal 7 ayat (1).

27 Pembentukan perundang-undangannya harus memperhatikan 2 klasifikasi yaitu asas-asas yang formal dan asas-asas yang materiil. Lihat I.C. Van Der Vlies dan A. Hamid S. Attamimi sebagaimana dikutip oleh Ferry Irawan Febriansyah, "Konsep Pembentukan Peraturan Perundang-undangan Di Indonesia", PERSPEKTIF Volume XXI No. 3 Edisi September (2016): 221. 
lebih lanjut serta bersifat hipotetif dan fiktif, yaitu kaidah dasar (Grundnorm) ${ }^{28}$ Selanjutnya Hans Nawiasky, mengembangkan teori ini secara lebih detail menjadi teori tata urutan kaidah hukum (die Theorie vom Stufenordnung der Rechtsnormen) dengan mengelompokkan jenjang atau lapisan kaidah hukum menjadi empat kelompok, yaitu Staatsfundamentalnorm (kaidah fundamental negara), Staatsgrundgesetz (aturan dasar negara/ aturan pokok negara), Formel Gesetz, (undang-undang 'formal'), serta Verordnung (aturan pelaksana) dan Autonom Satzung (aturan otonom). ${ }^{29}$ Jenis Peraturan perundang-undangan selain itu, ${ }^{30}$ mencakup peraturan yang ditetapkan antara lain oleh, Menteri, Pemerintah atas perintah UndangUndang, dan Gubernur. ${ }^{31}$ Peraturan perundang-undangan tersebut diakui keberadaannya dan mempunyai kekuatan hukum mengikat sepanjang diperintahkan oleh peraturan perundang-undangan yang lebih tinggi atau dibentuk berdasarkan kewenangan.

Tanggung jawab timbul karena adanya hak yaitu suatu kewenangan yang dimiliki guna melakukan sesuatu sesuai peraturan perundangundangan, ${ }^{32}$ dan kewajiban sebagai sesuatu berdasarkan keharusan. Menurut Kamus Besar Bahasa Indonesia, tanggung jawab adalah keadaan wajib menanggung segala sesuatunya atau fungsi menerima pembebanan, sebagai akibat sikap pihak sendiri atau pihak lain. Dengan demikian, tanggung jawab yaitu keadaan wajib dilakukan menanggung segala sesuatu yang menjadi akibat berdasarkan kewenangannya yaitu kekuasaan yang mendapat legitimasi berdasarkan hukum. Selanjutnya menurut Titik Triwulan pertanggungjawaban harus mempunyai dasar, yaitu hal yang menyebabkan timbulnya hak hukum untuk menuntut pihak lain sekaligus berupa hal yang melahirkan kewajiban hukum orang lain untuk memberi pertanggungjawabannya. ${ }^{33}$

Kewajiban Negara untuk menangani pandemi covid 19 berarti kewajiban negara dalam memenuhi hak kesehatan tersebut yang dijabarkan dalam Pasal 2. 1 International Covenant on Economic, Social, and Cultural Rights (ICESCR) yang berbunyi:

"Each State Party to the present Covenant undertakes to take steps, individually and through international assistance and co operation, especially economic and technical, to the maximum of its

${ }^{28}$ Hans Kelsen, General Theory of Law and State, diterjemahkan oleh Raisul Muftaqien, Teori Umum Tentang Hukum dan Negara, (Bandung: Penerbit Nusa Media, 2008), hlm. 179.

${ }_{29}$ Maria Farida Indrati S. Ilmu Perundang-undangan 1: Jenis, Fungsi, dan Materi Muatan, (Yogyakarta: Kanisius, 2007), hlm. 41-45. Lihat juga Nurfaqih Irfani, “Asas Lex Superior, Lex Specialis, dan lex Posterior: Pemaknaan, Problematika, dan Penggunaannya Dalam Penalaran dan Argumentasi HUKUM”, Jurnal Legislasi Indonesia Vol 16 No. 3 - September (2020) : 307.

${ }^{30}$ Lihat Pasal 7 ayat (1), UU No.15 Tahun 2019 loc.cit.

31 Penjelasan selengkapnya Lihat Pasal 8, ibid.

32 Johan Yasin, "Hak Azasi Manusia dan Hak Serta Kewajiban Warga Negara Dalam Hukum Positif Indonesia", https://ejournal.unisba.ac.id/ index.php/syiar_hukum/article/viewFile/541/pdf,(diakses 19 Januari 2021). hlm. 48 .

${ }^{33}$ Titik Triwulan dan Shinta Febrian, Perlindungan Hukum bagi Pasien, (Jakarta: Prestasi Pustaka, 2010), 
available resources, with a view to achieving progressively the full realization of the rights recognized in the present Covenant by all appropriate means, including particularly the adoption of legislative measures."

Selain itu, dikenal juga tiga bentuk kewajiban negara (generic obligation), yang mengikat Negara-negara peratifikasi perjanjian internasional hak-hak asasi manusia yaitu: ${ }^{34}$

a. Obligation to Respect (Kewajiban Untuk Menghormati)

Kewajiban negara untuk mencampuri baik secara langsung maupun tidak langsung pemenuhan hak atas kesehatan. Hal ini termasuk juga kewajiban untuk membatasi akses untuk semua orang terhadap pengobatan yang bersifat preventif, kuratif, dan paliatif.

b. Obligation to Protect (Kewajiban untuk Melindungi)

Kewajiban untuk mengambil langkah-langkah yang mencegah pihak ketiga mengganggu jaminan, termasuk juga memastikan akses yang setara terhadap perawatan kesehatan dari pihak ketiga, dan memastikan privatisasi dari sektor kesehatan tidak mengancam ketersediaan, aksesibilitas, akseptabilitas dan kualitas dari fasilitasfasilitas kesehatan, produk dan jasa.

c. Obligation to Fulfill (Kewajiban untuk Memenuhi):

Kewajiban untuk mengadopsi langkah-langkah legislatif, administratif, penganggaran, hukum, peningkatan dan tindakan tepat lainnya untuk realisasi penuh hak atas kesehatan, salah satunya dengan membuat kebijakan dan rencana kesehatan nasional yang mencakup sektor publik dan privat.

Implementasi bentuk Kewajiban Negara terkait dengan penanganan pandemi covid 19 adalah Obligation to Fulfill (Kewajiban untuk Memenuhi), hal ini dapat dilihat dari adanya upaya Negara (pemerintah) dalam membentuk perundang-undangan secara bertahap, menyediakan anggaran untuk penyediaan dan pelaksanaan vaksinasi dan tindakan untuk memenuhi hak atas kesehatan seperti melakukan PSBB dan menerapkan protol kesehatan bagi setiap anggota masyarakat secara nasional.

Menurut hukum nasional, kewajiban Negara (pemerintah) berkaitan penanganan pandemi covid 19 adalah memberdayakan dan mendorong peran aktif masyarakat dalam segala bentuk upaya kesehatan ${ }^{35}$ dan bertanggung jawab atas ketersediaan segala bentuk upaya kesehatan yang bermutu, aman, efisien, dan terjangkau. ${ }^{36}$ Di lain pihak, hak atas

${ }^{34}$ Mikho Ardinata, “Tanggung Jawab Negara Terhadap Jaminan Kesehatan Dalam Perspektif Hak Asasi Manusia", Jurnal HAM Volume 11, Nomor 2, Agustus (2020), hlm. 326.

35 Pasal 18 UU No. 36 Tahun 2009 tentang Kesehatan.

${ }^{36}$ Ibid, Pasal 19. 
kesehatan setiap orang sebagai warganegara adalah mendapatkan lingkungan yang sehat bagi pencapaian derajat kesehatan, ${ }^{37}$ dan berkewajiban berperilaku hidup sehat untuk mewujudkan, mempertahankan, dan memajukan kesehatan yang setinggi-tingginya. ${ }^{38}$

Tanggung jawab Negara melalui kebijakan perundang-undangan dalam penanganan pandemi covid 19 merupakan implementasi konsep negara kesejahteraan yang mengandung unsur dan karakteristik memberikan perlindungan sosial secara khusus yang menjadi sumber hukum dari semua hukum dari semua peraturan perundang-undangan dalam urusan sosial. ${ }^{39}$ Dalam kaitan ini, Friedman mengemukakan empat fungsi negara, antara lain yang terkait dengan penangan pandemi covid 19 yaitu sebagai regulator, artinya Negara mengadakan aturan kehidupan bernegara ${ }^{40}$ melalui fungsi legislasi sesuai dengan jenis dan muatan (asas formal dan materil) serta memperhatikan hierarkhi perundang-undangan.

Dinamika dan perkembangan peraturan pada masa terjadinya pandemi covid 19 merupakan bentuk tanggung jawab Negara melalui pengesahan peraturan perundangundangan secara bertahap. Dalam hal ini dapat dibagi dalam kategori peraturan yang terkait PSBB, pengadaan dan pelaksanaan vaksin, dan pelaksanaan protokol kesehatan. Jenis peraturan perundang-undangan tersebut meliputi Peraturan Pemerintah, Peraturan Presiden, Instruksi Presiden, Peraturan Menteri Kesehatan, dan Keputusan Direktur Jenderal sebagaimana diatur dalam Pasal 7 dan Pasal 8 UU No. 15 Tahun 2019 tentang Perubahan atas Undang-Undang Nomor 12 Tahun 2011 Tentang Pembentukan Peraturan Perundang-Undangan.

Peraturan perundang-undangan yang terkait dengan PSBB adalah:

\section{a. Peraturan Pemerintah Nomor 21 Tahun 2020 Tentang Pembatasan Sosial Berskala Besar dalam Rangka Percepatan Penanganan Corona Virus Disease 2019 (COVID-19)}

PSBB adalah pembatasan kegiatan tertentu penduduk dalam suatu wilayah yang diduga terinfeksi Corona Virus Disease 2019 (COVID-19) sedemikian rupa untuk

${ }^{37}$ Ibid, Pasal 6.

38 Ibid, Pasal 11.

39 Penjelasan selengkapnya tentang unsur dan karakteristik tanggung jawab Negara terkait Negara kesejehteraan, lihat Lukmanul Hakim, Kedudukan Hukum Komisi Negara di Indonesia; Eksistensi Komisi-komisi Negara (State Auxiliary Agency) Sebagai Organ Negara yang Mandiri Dalam Sistem Ketatanegaraan, Program Pasca Sarjana Universitas Brawijaya Malang, Puskasi Universitas Widyagama Malang dan Setara Press (Malang: Kelompok Penerbit Intrans, 2010), hlm. 48.

40 Selengkapnya Lukmanul Hakim, ibid, hlm. 49-50. Lihat juga Sudi Fahmi, “Asas Tanggung Jawab Negara Sebagai Dasar Pelaksanaan Perlindungan dan Pengelolaan Lingkungan Hidup”. Jurnal Hukum No. 2 Vol. 18 April (2011): 212 - 228. 
mencegah kemungkinan penyebaran COVID-19. Hal ini berbeda dengan "lockdown" yaitu suatu upaya pengendalian penyebaran infeksi yang mengharuskan sebuah wilayah menutup akses masuk maupun keluar sepenuhnya. Contoh di Wuhan, China lockdown yang diterapkan secara total, sehingga seluruh warga di kota tersebut dilarang keluar rumah dan semua area publik, seperti mall dan pasar, ditutup. Namun di Italia dan Spanyol, kebijakan lockdown masih memperbolehkan warganya pergi keluar rumah untuk berbelanja kebutuhan sehari-hari dan membeli obat-obatan. ${ }^{41}$

PSBB harus memenuhi kriteria jumlah kasus dan/atau jumlah kematian akibat penyakit meningkat dan menyebar secara signifikan dan cepat ke beberapa wilayah; dan terdapat kaitan epidemiologis dengan kejadian serupa di wilayah atau negara lain. PSBB paling sedikit meliputi peliburan sekolah dan tempat kerja; pembatasan kegiatan keagamaan; dan/atau pembatasan kegiatan di tempat atau fasilitas umum. Namun, pembatasan kegiatan tersebut harus tetap mempertimbangkan kebutuhan pendidikan, produktivitas kerja, dan ibadah penduduk dan dilakukan dengan memperhatikan pemenuhan kebutuhan dasar penduduk.

\section{b. Peraturan Menteri Kesehatan Nomor 9 Tahun 2020 tentang Pedoman Pembatasan Sosial Berskala Besar Dalam Rangka Percepatan Penanganan Corona Virus Disease 2019}

Penetapan PSBB dilakukan atas dasar peningkatan jumlah kasus secara bermakna dalam kurun waktu tertentu; terjadi penyebaran kasus secara cepat di wilayah lain dalam kurun waktu tertentu; dan ada bukti terjadi transmisi lokal. Selain itu, penetapan PSBB juga mempertimbangkan kesiapan daerah dalam hal-hal yang terkait dengan ketersediaan kebutuhan hidup dasar rakyat, ketersediaan sarana dan prasarana kesehatan, ketersediaan anggaran dan operasionalisasi jaring pengaman sosial untuk rakyat terdampak, dan aspek keamanan. Pelaksanaan PSBB dilaksanakan selama masa inkubasi terpanjang dan dapat diperpanjang jika masih terdapat bukti penyebaran, misalnya Gubernur DKI Jakarta, resmi memperpanjang penerapan PSBB selama dua pekan, hingga 8 Februari 2021. Keputusan perpanjangan tersebut tertuang dalam Keputusan Gubernur Nomor 51 Tahun 2021 tentang Perpanjangan Pemberlakuan, Jangka Waktu dan Pembatasan Aktivitas Luar. ${ }^{42}$

41 https://idcloudhost.com/mengenal-perbedaan-lockdown-dan-psbb-selama-pandemi-viruscorona-covid-19/(diak- ses 20 Januari 2021).

${ }^{42}$ https://www.cnnindonesia.com/nasional/20210124182820-20-597786/anies-perpanjang-psbbjakarta-hingga-8-fe- bruari-2021 (diakses 12 Februari 2021). 
KRTHA BHAYANGKARA | Volume 15 Number 2, December 2021

Peraturan perundang-undangan terkait pengadaan dan pelaksaan vaksin adalah:

a. Peraturan Presiden Nomor 99 Tahun 2020 Tentang Pengadaan Vaksin Dan Pelaksanaan Vaksinasi Dalam Rangka Penanggulangan Pandemi Corona Virus Disease 2019 (COVID-19).

Cakupan pelaksanaan pengadaan Vaksin dan pelaksanaan Vaksinasi COVID- 19 meliputi pengadaan Vaksin COVID-19; pelaksanaan Vaksinasi COVID-19; pendanaan pengadaan Vaksin COVID- 19 dan pelaksanaan Vaksinasi COVID- 19; dukungan dan fasilitas kementerian, lembaga, dan pemerintah daerah. Sedangkan pelaksanaan penetapan jenis dan jumlah Vaksin COVID-19 dilakukan oleh Menteri Kesehatan dengan memperhatikan pertimbangan Komite Penanganan COVID-19 dan Pemulihan Ekonomi Nasional. Pengadaan Vaksin COVID- 19 meliputi: penyediaan Vaksin COVID-19 dan peralatan pendukung dan logistik yang diperlukan; dan distribusi Vaksin COVID-19 sampai pada titik serah yang ditetapkan oleh Menteri Kesehatan.

b. Peraturan Menteri Kesehatan Nomor 84 Tahun 2020 tentang Pelaksanaan Vaksinasi Dalam Rangka Penanggulangan Pandemi Corona Virus Disease 2019 (Covid-19)

Pelaksanaan Vaksinasi COVID-19 bertujuan: untuk mengurangi transmisi/penularan COVID-19; angka kesakitan dan kematian akibat COVID-19; mencapai kekebalan kelompok di masyarakat; dan melindungi masyarakat dari COVID19 agar tetap produktif secara sosial dan ekonomi. Ruang lingkup pengaturannya meliputi: perencanaan kebutuhan Vaksinasi COVID-19; sasaran pelaksanaan Vaksinasi COVID19; distribusi Vaksin COVID-19, peralatan pendukung, dan logistik; pelaksanaan pelayanan Vaksinasi COVID-19; kerja sama dalam pelaksanaan Vaksinasi COVID-19; pemantauan dan penanggulangan Kejadian Ikutan Pasca Vaksinasi COVID-19; strategi komunikasi; pencatatan dan pelaporan; pendanaan; dan pembinaan dan pengawasan.

c. Keputusan Direktur Jenderal Pencegahan Dan Pengendalian Penyakit Nomor HK.02.02/4/ 1 /2021 Tentang Petunjuk Teknis Pelaksanaan Vaksinasi Dalam Rangka Penanggulangan Pandemi Corona Virus Disease 2019 (COVID-19) 
KRTHA BHAYANGKARA | Volume 15 Number 2, December 2021

COVID-19 merupakan penyakit menular yang disebabkan oleh Severe Acute Respiratory Syndrome Coronavirus 2 (SARS-CoV-2), jenis baru corona virus yang belum pernah diidentifikasi sebelumnya pada manusia yang telah dinyatakan sebagai bencana non-alam berupa wabah/pandemi maupun sebagai kedaruratan Kesehatan masyarakat. Karena itu, dalam rangka penanggulangan pandemi COVID-19 tidak hanya dilaksanakan dari sisi penerapan protokol kesehatan, namun juga intervensi dengan vaksinasi sebagai bagian dari upaya pencegahan dan Pengendalian COVID-19. Hal itu didasarkan atas rekomendasi dari Komite Penasihat Ahli Imunisasi Nasional (Indonesian Technology Advisory Group on Immunization) tahun 2020, untuk dapat mengendalikan pandemi COVID-19 di masyarakat secara cepat yaitu dengan meningkatkan kekebalan individu dan kelompok sehingga dapat menurunkan angka kesakitan dan kematian, serta mendukung produktifitas ekonomi dan sosial, serta pemberian vaksinasi COVID-19 dilakukan dengan strategi yang tepat pada kelompok sasaran prioritas.

Peraturan perundang-undangan terkait protokol kesehatan adalah:

\section{a. Instruksi Presiden Nomor 6 Tahun 2020 tentang Peningkatan Disiplin Dan Penegakan Hukum Protokol Kesehatan Dalam Pencegahan Dan Pengendalian CORONA Y/RUS D/SEASE 2019.}

Jimly Asshiddiqie berpendapat bahwa Instruksi Presiden merupakan "policy rules" atau "beleidsregels", yaitu bentuk peraturan kebijakan yang tidak dapat dikategorikan sebagai bentuk peraturan perundang-undangan yang biasa. Disebut "policy" atau "beleids" atau kebijakan karena secara formal tidak dapat disebut atau bukan berbentuk peraturan yang resmi. ${ }^{43}$ Namun, isinya bersifat mengatur (regeling) dan memberi petunjuk dalam rangka pelaksanaan pekerjaan, sehingga hanya terbatas untuk memberikan arahan, menuntun, membimbing dalam hal suatu pelaksanaan tugas. Hal ini berbeda dengan Keputusan Presiden, ada yang bersifat mengatur (regeling) atau Peraturan Presiden dan yang bersifatnya menetapkan (beschikking) ${ }^{44}$ atau Keputusan Presiden. Keputusan (beschikking) selalu bersifat individual, kongkret dan berlaku sekali selesai (enmablig), sedangkan, peraturan (regels) selalu bersifat umum, abstrak dan berlaku secara terus menerus (dauerhaftig). ${ }^{45}$

Instruksi Presiden No. 6 Tahun 2020 bertujuan dalam rangka menjamin kepastian hukum, memperkuat upaya dan meningkatkan efektivitas pencegahan dan pengendalian

\footnotetext{
43 https://www.hukumonline.com/klinik/detail/ulasan/lt50cf39774d2ec/peraturan-presiden/ (diakses 5 Februari 2021).

${ }^{44}$ Ibid.

45 https://www.hukumonline.com/klinik/detail/ulasan/lt4ffce5b9240c9/keputusan-presiden
} (diakses 7 Februari 2021). 
Covid-19 di seluruh daerah provinsi serta kabupaten/kota di Indonesia, dengan menginstruksikan: kepada para pejabat yang ditunjuk ${ }^{46}$ untuk mengambil langkah-langkah yang diperlukan sesuai tugas, fungsi, dan kewenangan masing-masing dalam menjamin kepastian hukum, memperkuat upaya dan meningkatkan efektivitas pencegahan dan pengendalian Covid-I9 di seluruh daerah provinsi serta kabupaten/kota di Indonesia.

\section{b. Keputusan Menteri Kesehatan Nomor HK.01.07/MENKES/382/2020 Tentang Protokol Kesehatan Bagi Masyarakat Di Tempat Dan Fasilitas Umum Dalam Rangka Pencegahan Dan Pengendalian Corona Virus Disease 2019 (COVID-19).}

Keputusan Menteri Kesehatan Nomor HK.01.07/MENKES/382/2020 ini digunakan sebagai acuan bagi kementerian/lembaga, pemerintah daerah provinsi, pemerintah daerah kabupaten/kota, dan masyarakat termasuk asosiasi, pengelola, pemilik, pekerja, dan pengunjung pada tempat dan fasilitas umum, serta komponen lain, baik dalam penetapan kebijakan, pembinaan aktivitas usaha, pelaksanaan usaha/kegiatan, aktivitas masyarakat, maupun dalam melakukan pengawasan kegiatan di tempat dan fasilitas umum, dalam rangka mencegah terjadinya episenter/kluster baru selama masa pandemi COVID-19. Penentuan tersebut disesuaikan dengan tingkat risiko wilayah penyebaran COVID-19 dan kemampuan daerah dalam mengendalikan COVID-19, yang mengacu pada ketentuan pemberlakuan pembukaan tempat dan fasilitas umum yang ditetapkan oleh pemerintah pusat atau pemerintah daerah/Gugus Tugas Percepatan Penanganan COVID-19 sesuai dengan kewenangannya dan dapat melibatkan masyarakat. Kebijakan untuk memilih opsi PSBB sebagaimana diatur dalam PP No. 21 Tahun 2020 jo Peraturan Menteri Kesehatan No. 9 Tahun 2020; Pengadaan vaksin dan pelaksanaan vaksinasi dalam Peraturan Presiden No. 99 Tahun 2020 jo Peraturan Menteri Kesehatan No. 84 Tahun 2020 jo Keputusan Direktur Jenderal Pencegahan Dan Pengendalian Penyakit Nomor HK.02.02/4/ 1 /2021; dan protokol kesehatan yang diatur dalam Inspres No. 6 Tahun 2020 dan Keputusan Menteri Kesehatan No. HK.01.07/MENKES/382/2020 merupakan kebijakan legislasi sebagai bentuk tanggung jawab Negara dalam memajukan kesejahteraan umum melalui pemenuhan hak atas kesehatan bagi setiap orang untuk mengimplementasikan konsep Negara kesejahteraan.

46 Selengkapnya lihat Instruksi Presiden Nomor 6 Tahun 2020 tentang Peningkatan Disiplin dan Penegakan Hukum Protokol Kesehatan Dalam Pencegahan Dan Pengendalian CORONA Y/RUS D/SEASE 2019. 


\section{Kendala Penanganan Pandemi Covid 19 Dalam Upaya Pemenuhan Tanggung Jawab Negara kendala dikaitkan dengan sistem hukum menurut Friedman}

Friedman berpedapat bahwa efektivitas suatu sistem hukum ditentukan oleh 3 unsur yang merupakan sub sistem, yaitu struktur hukum, substansi hukum dan budaya hukum.

Struktur hukum:

"The structure of a system is its skeleton or framework; it is the permanent shape, the institutional body of the system, the though rigid nones that keep the process flowing within bounds... The structure of a legal system consists of elements of this kind: the number and size of courts; their jurisdiction (that is, what kind of cases they hear, and how and why); and modes of appeal from one court to another. Structure also means how the legislature is organized, how many members, what a president can (legally) do or not do, what procedures the police department follows, and so on. Structure, in a way, is a kind of cross section of the legal system? A kind of still photograph, which freezes the action. ${ }^{\text {,47 }}$

Struktur adalah Pola yang menunjukkan tentang hukum menurut ketentuan formalnya dan menunjukkan pengadilan, pembuat hukum dan badan serta proses hukum itu dapat berjalan atau berkaitan dengan tatanan kelembagaan dan kinerja kelembagaan beserta dengan aparatnya dalam melaksanakan dan menegakkan hukum, termasuk di dalamnya pola bagaimana hukum itu dilaksanakan dan ditegakkan sesuai dengan aturan formalnya (menyangkut pula kinerja hukum). ${ }^{48}$ Struktur hukum terkait dengan penanganan pandemi covid 19 adalah Kepolisian sebagaimana diatur dalam Instruksi Presiden Nomor 6 Tahun 2020 tentang Peningkatan Disiplin dan Penegakan Hukum Protokol Kesehatan dalam Pencegahan dan Pengendalian Corona Virus Disease 2019. Selanjutnya keluar Maklumat Kapolri No. Mak/2/III/2020 tentang Kepatuhan Kebijakan Pemerintah dalam Penanganan Virus Corona untuk mendukung PP Nomor 21 Tahun 2020 dan Peraturan Menteri Kesehatan No. 9 Tahun 2020. Maklumat Kapolri ini menyatakan bahwa Polri mendukung penuh kebijakan pemerintah terkait penanganan COVID-19 dan memutus mata rantai wabah corona di Indonesia melalui penindakan kepada masyarakat yang masih berkumpul dan juga fokus pada penanganan kejahatan yang berpotensi terjadi saat penerapan PSBB, seperti street crime dan perlawanan terhadap

${ }^{47}$ Lawrence M. Friedman, Sistem Hukum; Perspektif Ilmu Sosial (The Legal System; A Social Science Perspective), (Bandung: Nusa Media, 2009), hlm. 20.

${ }^{48}$ Abdul Halim Barkatullah, "Budaya Hukum Masyarakat Dalam Perspektif Sistem Hukum”, http:// eprints.ulm. ac.id / 138/1/Jurnal\%20UKSW Budaya\%20Hukum\%20.pdf (diakses 5 Februari 2021). 
petugas. $^{49}$ Dalam Instruksi Presiden Nomor 6 Tahun 2020, kepolisian diinstruksikan melakukan pembinaan masyarakat untuk berpartisipasi dalam upaya pencegahan dan pengendalian COVID19 dan mengefektifkan upaya penegakan hukum terhadap pelanggaran protokol kesehatan, tetapi bukan berarti pendekatan pidana penjara harus dilakukan terhadap pelanggaran PSBB atau protokol kesehatan, karena pada saat yang sama, pemerintah telah membebaskan lebih dari 36.000 narapidana agar mengurangi potensi penyebaran Covid-19 di Lembaga Pemasyarakatan. ${ }^{50}$ Di sisi lain hukum pidana sebagai ultimum remedium, menekankan bahwa fungsi itu oleh penegak hukum harus digunakan sebagai upaya terakhir apabila hukum-hukum lainnya tidak dapat dilakukan. Lebih lanjut, Kepala daerah baik Gubernur maupun Bupati/Walikota telah mengeluarkan kebijakan demi peningkatan disiplin protokol kesehatan dalam pencegahan dan pengendalian Covid-19 untuk menetapkan petugas sesuai dengan keadaan masing-masing daerah. Misalnya, Gugus Tugas Percepatan Penanganan COVID-19 (GTTPC19) tidak hanya melakukan pengendalian penyebaran virus SARS-CoV-2 atau penanganan dampak di sektor ekonomi, sosial maupun budaya, tetapi penanganan juga dilakukan termasuk dalam pengamanan dan penegakan hukum di masa pandemi. Selama pelaksanaan pembatasan sosial, gugus tugas telah membuat pos checkpoint, khususnya di wilayah DKI Jakarta dengan jumlah 524, sedangkan pos di luar DKI Jakarta, sebanyak 2.374 pos di wilayah Jawa Barat, Jawa Tengah dan Jawa Timur. ${ }^{51}$ Hal itu menunjukan bahwa terlepas masih perlu pembenahan dan peningkatan konsisten penegak hukum, tetapi struktur hukum tersebut dalam perspektif sistem hukum menurut Friedman untuk penanganan pandemi covid 19 dapat diandalkan.

Substansi Hukum:

"The substance is composed of substantive rules and rules about how institutions should behave. By this is meant the actual rules, norm, and behavioral patterns of people inside the system ...the stress here is on living law, not just rules in law books". ${ }^{2}$

49 Sarah Nuraini Siregar, Politik Nasional:” Polri di Masa Pandemi COVID-19 : Kompleksitas Masalah Penegakan Hukum dan Pilihan Solusihttp://politik.lipi.go.id/kolom/kolom-2/politiknasional/1391-polri-di-masa-pandemi-covid-19-kompleksitas-masalah-penegakan-hukum-dan-pilihansolusi (diakses 7 Februari 2021).

50 Dani Prabowo, "Darurat Kesehatan, Penegak Hukum Diminta Tak Mudah Penjarakan Masyarakat", https://nasional.kompas.com/read/2020/04/15/10292281/darurat-kesehatan-penegakhukum-diminta-tak-mudah-penjarakan-masyarakat (diakses 7 Februari 2021).

$51 \quad$ https://www.msn.com/id-id/berita/nasional/begini-upaya-pengamanan-dan-penegakanhukum-di-masa-pandemi-covid-19/ar-BB15ujgh (diakses 7 Februari 2021).

${ }^{52}$ Ibid. 
Substansi berarti aturan, norma, dan pola perilaku orang-orang di dalam sistem yang sebenarnya ... penekanannya adalah hukum hidup (living law), bukan hanya peraturan dalam perundang-undangan (law in book)." Substansi atau isi hukum sebagai acuan dalam penegakan hukum mempunyai peran penting sebagai pedoman atau pegangan bagi penegak hukum dalam melakukan wewenangnya. Hal ini berarti kelemahan isi hukum mengakibatkan penegakan hukum tidak efektif sehingga tujuan yang hendak dicapai tidak terpenuhi.

Substansi hukum dalam arti jenis dan muatan peraturan dalam penanganan covid 19 berkaitan PSBB sebagaimana tercantum dalam PP No. 21 Tahun 2000 sudah memenuhi "asas kejelasan tujuan" dan "asas kedayagunaan dan kehasilgunaan" dalam pembentukan peraturan perundang-undangan dan asas materi muatan peraturan perundang-undangan "asas pengayoman", "asas kemanusiaan", "asas kenusantaraan", "asas keadilan", "asas kesamaan kedudukan dalam hukum dan pemerintahan" tercantum dalam Dasar pertimbangan dikeluarkannya PP ini, ${ }^{53}$ kesejahteraan masyarakat di Indonesia; kedua, dampak penyebaran COVID-19. Sedangkan "asas kesesuaian antara jenis, hierarki, dan materi muatan" dalam pembentukan peraturan perundang-undangan dan asas materi muatan" "asas ketertiban dan kepastian hukum” tersurat dalam poin "mengingat" yang mengacu ke berbagai peraturan perundang-undangan, yaitu Pasal 5 ayat (2) UUD 1945; UU No. 4 Tahun 1984 tentang Wabah Penyakit; UU No. 24 Tahun 2007 tentang Penanggulangan Bencana; UU No. 6 Tahun 2018 tentang Kekarantinaan Kesehatan.

Makna, kriteria dan persyaratan PSBB dalam PP tersebut mencerminkan "asas kejelasan rumusan" dan "asas kesesuaian antara jenis, hierarki, dan materi muatan" sebagai asas pembentukan peraturan perundang-undangan" dan asas keseimbangan, keserasian, dan keselarasan" sebagai pemenuhan asas muatan peraturan perundang-undangan. Lebih lanjut, dari sisi hierarki perundang-undangan PP No. 21 Tahun 2020 sudah sesuai sebagai peraturan pelaksana dari UU No. 4 Tahun 1984 tentang Wabah Penyakit Menular; UU No. 24 Tahun 2007 tentang Penanggulangan Bencana; dan UU No. 6 Tahun 2018 tentang Kekarantinaan Kesehatan. Demikian pula dengan jenis, materi muatan berkaitan dengan substansi peraturan tentang pengadaan dan pelaksanaan vaksin Perpres No. 99 Tahun 2020 jo Peraturan Menteri Kesehatan No. 84 Tahun 2020 jo Keputusan Direktur Jenderal Pencegahan Dan Pengendalian Penyakit Nomor HK.02.02/4/ 1 /2021 telah

${ }^{53}$ Lihat Bagian Menimbang PP No. 21 Tahun 2000 Tentang Pembatasan Sosial Berskala Besar dalam Rangka Percepatan Penanganan Corona Virus Disease 2019 (COVID-19). 
sesuai dengan jenis, asas, muatan dan hirarkhi yang tercantum dalam UU No. 15 Tahun 2019 dan UU No. 2 Tahun 2020 tentang Penetapan Peraturan Pemerintah Pengganti Undang-Undang Nomor 1 Tahun 2020 tentang Kebijakan Keuangan Negara dan Stabilitas Sistem Keuangan untuk Penanganan Pandemi COVID-L9. Selanjutnya, terkait protokol kesehatan sebagaimana diatur melalui Instruksi Presiden No. 6 Tahun 2020 dan Keputusan Menteri Kesehatan No. HK.01.07/MENKES/382/2020 juga sudah sesuai dengan jenis, asas, muatan dan hirarkhi dalam ketentuan tentang pembentukan peraturan perundang-undangan.

Budaya Hukum:

The legal culture, system their beliefs, values, ideas and expectation. Legal culture refers, then, to those ports of general culture customs, opinions ways of doing and thinking that bend social forces toward from the law and in particular ways. ... in other word, is the climinate of social thought and social force wicch determines how law is used, avoided, or abused."

Budaya hukum mengacu pada budaya umum, pendapat dan berpikir yang mengarahkan kekuatan sosial ke arah hukum tertentu ... Dengan kata lain, puncak dari pemikiran sosial dan kekuatan sosial menentukan bagaimana hukum digunakan, dihindari, atau disalahgunakan.

Efektivitas Budaya hukum dalam arti tercapainya prilaku yang diharapkan (das sein) sesuai dengan norma (das sollen) terkait PSBB masih ada kendala, misalnya Keberhasilan PSBB dibuktikan dengan pelaksanaan PSBB berjalan dengan baik, penurunan jumlah kasus, dan tidak ada penyebaran ke arah atau wilayan baru, ${ }^{54}$ tetapi kenyataannya jumlah Kasus positif Covid-19 bertambah. Tercatat pada 1 Februari 2021 bertambah 10.994 kasus menjadi 1.089.308 di 10 provinsi. Jumlah ini merupakan hasil tracing melalui pemeriksaan sebanyak 48.213 spesimen yang dilakukan dengan metode real time polymerase chain reaction (PCR) dan tes cepat molekuler (TCM) ${ }^{55}$ Pengadaan dan pelaksanaan vaksin, diduga adanya penyelewengan sehingga Komisi Pemberantasan Korupsi (KPK) bersama instansi terkait lainnya mengawal dan memberikan masukan atas langkah-langkah pemerintah dalam pengadaan dan distribusi vaksin Covid-19, termasuk alat kesehatan pendukung vaksinasi. Kondisi tidak normal ini tantangan bagi pemerintah untuk memastikan bahwa setiap prosesnya dilakukan secara transparan dan akuntabel. ${ }^{56}$ Selanjutnya, tenaga kesehatan yang tidak datang dengan berbagai alasan ke tempat

54 https://www.jurnalhukum.com/pembatasan-sosial-berskala-besar/ (diakses 8 Februari 2021).

55 https://www.inews.id/news/nasional/kasus-covid-naik-10994-orang-ini-10-provinsipenambahan-terbanyak (diak- ses 9 Februari 2021).

56 https://nasional.kompas.com/read/2021/02/03/10411081/terus-kawal-pengadaan-dan-distribusi-vaksin-covid-19-ini-rekomendasi-kpk (diakses 9 Februari 2021). 
vaksinasi sesuai dengan jadwal yang telah ditentukan padahal vaksinasi diprioritaskan untuk para tenaga kesehatan, baik dokter maupun perawat sebagai garda terdepan dalam penanganan pandemi covid $19^{57}$ dan pihak yang menolak untuk divaksinasi semakin memperlemah penanganan pandemi covid 19.

Budaya hukum untuk menjalankan prosedur penanganan (preventif) pandemi covid 19 masih mengalami kendala karena kurang kesadaran hukum masyarakat untuk mematuhi peraturan. Dalam penerapannya, pada saat ini masih ada tempat umum seperti pasar atau taman yang belum memiliki fasilitas mencuci tangan dan kurang konsistennya dalam pengaturan jarak mes kipun untuk pembersihan dan disinfektasi lingkungan secara berkala telah dilakukan sesuai dengan yang diinstruksikan. Namun, dalam beberapa bulan terakhir terlihat kesadaran masyarakat terhadap bahaya Covid-19 mulai menurun. Hal tersebut terlihat dari banyaknya masyarakat yang tidak menggunakan masker di tempat umum, tidak menjaga jarak di keramaian, ${ }^{58}$ bahkan malas mencuci tangan. Kendala lainnya sebagaimana diberitakan Litbang Kompas adalah kurang siapnya masyarakat menjalani fase normal baru ${ }^{59}$ (new normal) yang memerlukan adaptasi pola prilaku individu di dalam masyarakat.

Soerjono Soekanto mengatakan bahwa kesadaran hukum adalah konsepsi abstrak dalam diri manusia tentang keserasian antara ketertiban dan ketentraman atau yang sepantasnya. ${ }^{60}$ Kesadaran hukum berbeda dengan kepatuhan hukum meskipun keduaduanya dikonkritkan dalam sikap dan tindakan atau perikelakuan manusia dalam bermasyarakat. Menurut Max Weber, kepatuhan hukum berkaitan dengan paksaan yaitu sanksi, sehingga seseorang mentaati hukum karena takut terhadap sanksi yang dapat diterimanya. Contoh pemberlakuan PSBB atau protokol kesehatan cenderung ditaati karena ada konsekuensi sanksi sosial atau sanksi hukum (denda) yang akan dikenakan apabila melanggar, sehingga dasar kepatuhannya adalah kemanfaatan sebagaimana ulitity theory yang dikemukakan oleh Biersted yaitu adanya patokan sebagai pedoman tentang tingkah laku dan dinamakan kaedah, sehingga salah satu faktor yang menyebabkan orang taat pada PSBB atau protokol kesehatan adalah kegunaan dari pada kaedah tersebut untuk

\footnotetext{
${ }^{57}$ https://www.kompas.com/tren/read/2021/02/01/093200165/vaksinasi-covid-19-tak-berjalansesuai-rencana-awal -apa-akibatnya-(diakses 10 Februari 2021).

58 Novita Listyaningrum dan Rinda Philona, "Penegakan hukum Protokol Kesehatan Di Masa Pandemi, (2021): 4737. http://ejurnal.binawakya.or.id/index.php/MBI Vol.15 No.7 Februari 2021 (diakses 4 Januari 2021).

${ }^{59}$ https ://kompaspedia. kompas.id/baca/ paparan-topik/ merunut-kebijakan-penanganan-wabahcovid-19-di-indonesia (diakses 9 Febrauari 2021).

${ }^{60}$ Sudjana, "Penyuluhan Hukum Dalam Upaya Peningkatan Kesadaran Hukum Berlalulintas Melalui Pemahaman Terhadap Isi Undang-Undang Nomor 22 Tahun 2009 Tentang Lalu Lintas Dan Angkutan Jalan”, JPIS, Jurnal Pendidikan Ilmu Sosial, Vol. 25, No. 2, Edisi Desember (2016): 13.
} 
hidup pantas dan teratur, ${ }^{61}$ dan individu atau masyarakat yang bersangkutan mendapatkan manfaat terhindar dari sanksi tersebut. Sedangkan dalam kesadaran hukum, pentaatan timbul dengan sendirinya berdasarkan hati nurani tanpa paksaan ${ }^{62}$ atau sanksi misalnya kesiapan untuk di vaksinasi agar dapat "internalize" ("mendarahdaging") harus melalui tahapan yaitu pengetahuan hukum, pemahaman hukum, sikap hukum, dan pola prilaku hukum. ${ }^{63}$

Pemerintah Pusat melalui Gugus Tugas Percepatan Penanganan COVID-19 membuat empat strategi yang secara konsisten dilakukan untuk menguatkan kebijakan physical distancing sebagai strategi dasar demi mengatasi pandemi COVID-19. Strategi pertama sebagai penguatan strategi dasar itu adalah dengan gerakan masker untuk semua yang mengampanyekan kewajiban memakai masker saat berada di ruang publik atau di luar rumah. Strategi kedua, adalah penelusuran kontak (tracing) dari kasus positif yang dirawat dengan menggunakan rapid test atau tes cepat. Di antaranya adalah pada orang terdekat, tenaga kesehatan yang merawat pasien COVID-19, serta pada masyarakat di daerah yang ditemukan kasus banyak. Strategi ketiga adalah edukasi dan penyiapan isolasi secara mandiri pada sebagian hasil tracing yang menunjukan hasil tes positif dari rapid tes atau negatif dengan gejala untuk melakukan isolasi mandiri. Strategi keempat adalah isolasi Rumah Sakit yang dilakukan kala isolasi mandiri tidak mungkin dilakukan, seperti karena ada tanda klinis yang butuh layanan definitif di Rumah Sakit. ${ }^{64}$ Namun, tanggung jawab negara dalam penanganan pandemi covid dalam rangka mengimplementasikan konsep negara kesejahteraan tidak hanya dilakukan melalui strategi kesehatan, tetapi juga pentingnya pendekatan hukum melalui kebijakan legislasi secara bertahap dengan memperhatikan efektivitasnya yaitu dengan struktur hukum, substansi hukum, dan budaya hukum yang kondusif sebagaimana dikemukakan oleh Friedman.

\section{KESIMPULAN}

Tanggung jawab Negara melalui kebijakan perundang-undangan secara bertahap sesuai situasi dan kondisi dalam penanganan pandemi covid 19 sudah mengimplementasikan konsep negara kesejahteraan karena fungsi Negara sebagai regulator telah melakukan obligation to fulfill (kewajiban untuk memenuhi) dan memiliki karakter sebagai dasar yang

${ }^{61}$ Ibid, hlm 5.

${ }^{62} \mathrm{Ibid}, \mathrm{hlm} .4$.

${ }^{63}$ Ellya Rosana, "Kepatuhan Hukum Sebagai Wujud Kesadaran Hukum Masyarakat", Jurnal TAPIs Vol.10 No.1 Januari-Juni (2014): 7.

64 Agus Wibowo Kepala Pusat Data Informasi dan Komunikasi Kebencanaan BNPB, https:// covid19.go.id/p/ berita/empat-strategi- pemerintah-atasi-covid-19(diakses 5 Februari 2021). 
memberikan perlindungan sosial secara khusus yang menjadi sumber hukum dari semua peraturan perundang-undangan dalam urusan sosial. Kendala dalam menghadapi pandemi covid 19 sebagai upaya pemenuhan tanggung Jawab Negara dikaitkan dengan sistem hukum menurut Friedman terletak pada masih rendahnya budaya hukum (legal culture) masyarakat dalam mentaati hukum atau peraturan berkaitan dengan penanganan pandemi covid 19.

\section{Saran}

Karena itu, untuk mendukung tanggung jawab negara dalam merealisasikan konsep negara hukum perlu partisipasi aktif seluruh anggota masyarakat, sehingga setiap kebijakan legislasi bersifat "bottom-up planning" bukan "top-down planning”, artinya menperkuat partisipasi masyarakat melalui wakilnya di Parlemen, sedangkan peran utama negara sebagai fasilitator. Selain itu perlunya upaya meningkatkan kesadaran hukum dalam membangun budaya hukum yang kondusif terkait penanganan pandemi covid 19, seperti budaya malu dan merasa bersalah apabila melanggar hukum (shame culture and guilty feeling) terkait peraturan tentang PSBB, protokol kesehatan, kesediaan untuk melakukan vaksinasi, dan mendukung kebijakan pemerintah melalui "masyarakat sadar covid 19."

\section{DAFTAR PUSTAKA}

\section{Buku}

Friedman, Lawrence M, Sistem Hukum; Perspektif Ilmu Sosial (The Legal System; ASocial Science Perspective), (Bandung: Nusa Media, 2009). Friedman, Lawrence M, Sistem Hukum; Perspektif Ilmu Sosial (The Legal System; A Social Science Perspective), (Bandung: Nusa Media, 2009).

Indrati S, Maria Farida. Ilmu Perundang-undangan 1: Jenis, Fungsi, dan Materi Muatan, (Yogyakarta: Kanisius, 2007).

Kelsen, Hans, General Theory of Law and State, diterjemahkan oleh Raisul Muftaqien, Teori Umum Tentang Hukum dan Negara, (Bandung: Penerbit Nusa Media, 2008).

Marzuki, Peter Mahmud, Penelitian Hukum (Jakarta: Kencana Prenada Media Group, 2009).

MD, Mahfud, Politik. Hukum di Indonesia (Jakarta: Rajawali, 2010). 2011). Membangun Politik Hukum, menegakkan Konstitusi Jakarta: Rajawali Press,

Mulyadi, Dedy, Studi Kebijakan Publik dan Pelayanan Publik (Bandung: Penerbit Alfabeta, 2015). 
Soekanto, Soerjono \& Sri Mamudji, Penelitian Hukum Normatif (Suatu Tinjanan Singkat), (Jakarta: Rajawali Pers, 2011).

Sutrisno, Edy, Mengenal Perencanaan, Implementsi \& Evaluasi Kebijakan/Program, (Surabaya: Penerbit, Untag Press, 2009).

Triwulan, Titik dan Shinta Febrian, Perlindungan Hukum bagi Pasien, (Jakarta: Prestasi Pustaka, 2010).

\section{Makalah/Artikel/Prosiding/Hasil Penelitian}

Utami, Penny Naluria. "Pencegahan Kekerasan Terhadap Anak Dalam Perspektif Hak Atas Rasa Aman Di Nusa Tenggara Barat.” Jurnal HAM 9, no. 1 (2018): 1-17.

Adityo Susilo et al, Coronavirus Disease 2019: "Tinjauan Literatur Terkini Coronavirus Disease 2019: Review of Current Literatures”, Jurnal Penyakit Dalam Indonesia Vol. 7, No. 1 Maret (2020): 46.

Agustino, Leo, "Analisis Kebijakan Penanganan Wabah COVID-19: Pengalaman Indonesia, Jurnal Borneo Administrator, Vol. 16 No. 2, 253-270, Agustus (2020): 254.

Ardinata, Mikho, "Tanggung Jawab Negara Terhadap Jaminan Kesehatan Dalam Perspektif Hak Asasi Manusia", Jurnal HAM Volume 11, Nomor 2, Agustus (2020):326.

Fahmi, Sudi, “Asas Tanggung Jawab Negara Sebagai Dasar Pelaksanaan Perlindungan dan Pengelolaan Lingkungan Hidup”. Jurnal Hukum No. 2 Vol. 18 April (2011): 212 228.

Febriansyah, Ferry Irawan, "Konsep Pembentukan Peraturan Perundang-undangan Di Indonesia”, PERSPEKTIF Volume XXI No. 3 Edisi September (2016): 221.

Hakim, Lukmanul, Kedudukan Hukum Komisi Negara di Indonesia; Eksistensi Komisi-komisi Negara (State Auxiliary Agency) Sebagai Organ Negara yang Mandiri Dalam Sistem Ketatanegaraan, Program Pasca Sarjana Universitas Brawijaya Malang, Puskasi Universitas Widyagama Malang dan Setara Press (Malang: Kelompok Penerbit Intrans, 2010): 48.

Huang C, Wang Y, Li X, Ren L, Zhao J, Hu Y, et al. "Clinical features of patients infected with 2019 novel coronavirus in Wuhan, China". Lancet. 2020:395 (10223):497506.

Irfani, Nurfaqih, "Asas Lex Superior, Lex Specialis, dan lex Posterior: Pemaknaan, Problematika, dan Penggunaannya Dalam Penalaran dan Argumentasi HUKUM”, Jurnal Legislasi Indonesia Vol 16 No. 3 - September (2020): 307.

Rosana, Ellya, “Kepatuhan Hukum Sebagai Wujud Kesadaran Hukum Masyarakat”, Jurnal TAPIs Vol.10 No.1 Januari-Juni (2014): 7.

Rothan HA, Byrareddy SN. "The epidemiology and pathogenesis of coronavirus disease (COVID-19) outbreak. J Autoimmun. 2020"; published online March 3. DOI: 10.1016/j.jaut.2020.102433 (diakses 4 Januari 2021).

Silviana, Ana, "Kajian Tentang Kesadaran Hukum Masyarakat dalam Melaksanakan Pendaftaran Tanah”, Jurnal Pandecta Volume 7. Nomor 1 Januari (2012): 115. 
Sudjana, "Penyuluhan Hukum Dalam Upaya Peningkatan Kesadaran Hukum Berlalulintas Melalui Pemahaman Terhadap Isi Undang-Undang Nomor 22 Tahun 2009 Tentang Lalu Lintas Dan Angkutan Jalan”, JPIS, Jurnal Pendidikan Ilmu Sosial, Vol. 25, No. 2, Edisi Desember (2016): 13.

\section{Internet}

Aida, N.R. "Rekap Perkembangan Virus Corona Wuhan dari Waktu ke Waktu". (Kompas Online, Januari 28, 2020, hlm 1-2),https://www. kompas.com/tren/read/2020/01/ 28/054600665/rekap-perkembanganviruscorona-wuhan-dari-waktu-ke-waktu (diakses 7 Janu- ari 2021).

Barkatullah, Abdul Halim, "Budaya Hukum Masyarakat Dalam Perspektif Sistem

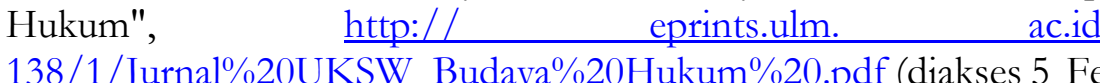
138/1/Jurnal\%20UKSW Budaya\%20Hukum\%20.pdf (diakses 5 Februari 2021).

Kamus Bahasa Indonesia, https://carapedia.com/pengertian definisi peraturan info2113.html (diakses 14 Januari 2021).

Luthfia Ayu Azanella, "Kasus Covid-19 Hampir 1 Juta, Penanganan Pandemi di Indonesia Belum "On the Right Track", https://www.kompas. $\mathrm{com} / \mathrm{tren} / \mathrm{read} / 2021 / 01 / 26 / 125900965 /$ kasus-covid-19-hampir-1-jutapenanganan-pandemi-di-indonesia-belum-on-the (diakses 13 Januari 2021).

H.P, Sari, "Indonesia Disebut Berpotensi Jadi Episentrum Baru Covid-19, Ini Respons Jubir Pemerintah". (Kompas Online, 11 April 2020). Retrieved from https://nasional. Kompas com/read/ 2020/04/11/ 20351811/ indonesiadisebut berpotensi-jadi-episentrum-baru-covid-19-ini-respons-jubir (diakses 10 Januari 2021).

Fitriana, Mia Kusuma, "Peranan Politik Hukum Dalam Pembentukan Peraturan Perundang-Undangan Di Indonesia Sebagai SArana Mewujudkan Tujuan Negara", Jurnal Legislasi Indonesia, (2018):7. https://ejurnal.peraturan.go.id/index.php/jli/issue/view/65 (diakses 17 Januari 2021).

https://idcloudhost.com/mengenal-perbedaan-lockdown-dan-psbb-selama-pandemivirus-corona-covid -19/(diakses 20 Januari 2021).

https://www.kompasiana.com/icai/54ff1 feda333112e4550f95f/indikator-kesejahteraan (diakses 3 Januari 2021).

https://kompaspedia.kompas.id/baca/paparan-topik/merunut-kebijakan-penangananwabah-covid-19-di-indonesia (diakses 12 Januari 2021).

https://www.kompas.com/covid-19 (diakses 13 Januari 2021).

http:// id.shvoong.com/ writing-and-speaking/ presenting/2202699- pengertiankebijakan/ \# ixzz2Fs6 QdboO, (diakses 16 Januari 2021).

https://www.hukumonline.com/klinik/detail/ulasan/lt50cf39774d2ec/peraturanpresiden/ (diakses 5 Februari 2021).

https://www.hukumonline.com/klinik/detail/ulasan/lt4ffce5b9240c9/keputusanpresiden (diakses 7 Feruari 2021). 
https://www.jurnalhukum.com/pembatasan-sosial-berskala-besar/ (diakses 8 Februari 2021).

https://www.inews.id/news/nasional/kasus-covid-naik-10994-orang-ini-10-provinsipenambahan- terbanyak (diakses 9 Februari 2021).

https://nasional.kompas.com/read/2021/02/03/10411081/terus-kawal-pengadaandan-distribusi-vak- sin-covid-19-ini-rekomendasi-kpk (diakses 9 Februari 2021).

https://kompaspedia.kompas.id/baca/paparan-topik/merunut-kebijakan-penangananwabah-covid-19-di-indonesia (diakses 9 Febrauari 2021).

https://www.kompas.com/tren/read/2021/02/01/093200165/vaksinasi-covid-19-takberjalan-sesu- ai-rencana-awal-apa -akibatnya-(diakses 10 Februari 2021).

https://www.cnnindonesia.com/nasional/20210124182820-20-597786/aniesperpanjang-psbb-ja- karta-hingga-8-februari-2021 (diakses 12 Februari 2021).

Listyaningrum, Novita dan Rinda Philona, "Penegakan hukum Protokol Kesehatan Di Masa Pandemi, (2021): 4737. http://ejurnal.binawakya.or.id/index.php/MBI Vol.15 No.7 Februari 2021 (diakses 4 Januari 2021).

Ren L-L, Wang Y-M, Wu Z-Q, Xiang Z-C, Guo L, Xu T, et al. "Identification of a novel coronavirus causing severe pneumonia in human: a descriptive study". Chin Med J. 2020; published online February 11. DOI: 10.1097/CM9.0000000000000722 (diakses 4 Januari 2021).

Park, S.N. (2020). "Cults and Conservatives Spread Coronavirus in South Korea Seoul seemed to have the virus under control. But religion and politics have derailed plans". (Foreign Policy Online, 27 Februari 2020). Retrieved from https://foreignpolicy.com/ 2020/02/27/coronavirus-south-korea-cultsconservativeschina/ (diakses 9 Januari 2021).

Prabowo, Dani, "Darurat Kesehatan, Penegak Hukum Diminta Tak Mudah Penjarakan Masyarakat", https://nasional.kompas.com/read/2020/04/15/10292281/darurat-kesehatanpenegak-hukum-diminta-tak-mudah-penjarakan-masyarakat (diakses 7 Februari 2021).

Siregar, Sarah Nuraini, Politik Nasional:" Polri di Masa Pandemi COVID-19: Kompleksitas Masalah Penegakan Hukum dan Pilihan Solusi." http://politik.lipi.go.id/kolom/kolom-2/politik-nasional/1391-polri-di-masapandemi-covid-19-kompleksitas-masalah-penegakan-hukum-dan-pilihan-solusi (diakses 7 Februari 2021).

Wibowo, Agus. Kepala Pusat Data Informasi dan Komunikasi Kebencanaan BNPB, https:// covid19.go.id/p/ berita/empat-strategi- pemerintah-atasi-covid-19 (diakses 5 Februari 2021).

Yasin, Johan, "Hak Azasi Manusia dan Hak Serta Kewajiban Warga Negara Dalam Hukum Positif Indonesia", https://ejournal.unisba.ac.id/ index.php/syiar hukum/article/viewFile/541/pdf, (diakses 19 Januari 2021).

\section{Peraturan Perundang-Undangan}

Undang-Undang Dasar Negara Republik Indonesia Tabun 1945. Republik Indonesia, 1945. 
KRTHA BHAYANGKARA | Volume 15 Number 2, December 2021

Undang-Undang Negara Republik Indonesia Nomor 36 Tahun 2009 Tentang Kesehatan.

Undang-Undang Negara Republik Indonesia Nomor 6 Tahun 2018 tentang Kekarantinaan Kesehatan.

Undang-Undang Negara Republik Indonesia Nomor 15 Tahun 2019 Tentang Perubahan Undang-Undang Nomor 12 Tahun 2011 Tentang Pembentukan Peraturan Pertundang-undangan.

Peraturan Pemerintah Republik Indonesia Nomor 21 Tahun 2020 Tentang Pembatasan Sosial Berskala Besar dalam Rangka Percepatan Penanganan Corona Virus Disease 2019 (COVID-19).

Peraturan Presiden Republik Indonesia Nomor 99 Tahun 2020 Tentang Pengadaan Vaksin Dan Pelaksanaan Vaksinasi Dalam Rangka Penanggulangan Pandemi Corona Virus Disease 2019 (COVID-19).

Peraturan Menteri Kesehatan Republik Indonesia Nomor 9 Tahun 2020 tentang Pedoman Pembatasan Sosial Berskala Besar Dalam Rangka Percepatan Penanganan Corona Virus Disease 2019.

Peraturan Menteri Kesehatan Republik Indonesia Nomor 84 Tahun 2020 tentang Pelaksanaan Vaksinasi Dalam Rangka Penanggulangan Pandemi Corona Virus Disease 2019 (Covid-19).

Keputusan Menteri Kesebatan Republik Indonesia Nomor HK.01.07/MENKES/382/2020 Tentang Protokol Kesehatan Bagi Masyarakat Di Tempat Dan Fasilitas Umum Dalam Rangka Pencegahan Dan Pengendalian Corona Virus Disease 2019 (COVID-19).

Keputusan Direktur Jenderal Pencegahan Dan Pengendalian Penyakit Nomor HK.02.02/4/ 1 /2021 Tentang Petunjuk Teknis Pelaksanaan Vaksinasi Dalam Rangka Penanggulangan Pandemi Corona Virus Disease 2019 (COVID-19). 